\title{
気泡トラップによるマイクロチャネル内スリップ流形成過程の可視化
}

\author{
山本 憲"1，廣瀬 雄哉*2，武澤 英之 ${ }^{* 3}$ ，小方 聡*2
}

\section{Visualization of the formation process of slip flows by the air entrapment in microchannels}

\author{
Ken YAMAMOTO $^{* 1}$, Yuya HIROSE ${ }^{* 2}$, Hideyuki TAKEZAWA ${ }^{* 3}$ and Satoshi OGATA ${ }^{* 2}$ \\ ${ }^{* 1}$ Department of Mechanical Engineering, Tokyo University of Science \\ 6-3-1 Niijuku, Katsushika-ku, Tokyo 125-8585, Japan \\ ${ }^{* 2 * 3}$ Department of Mechanical Engineering, Tokyo Metropolitan University \\ 1-1 Minami-osawa, Hachioji-shi, Tokyo 192-0397, Japan
}

Received 3 August 2016

\begin{abstract}
Processes of the air entrapment in microstructures fabricated on walls of rectangular microchannels were visualized by a high-speed camera. Effects of the geometry of the microstructures on the formation and the shape of the liquid-gas interface in the microstructures were investigated with four channels having the same dimensions but different microstructure geometries at $R e=1$. The microchannels were made of stainless steel and acrylic, and the microstructures were hydrophobized by triazinethiol. Water-ethanol mixtures with different mixing rate (ranged from 100:0 to 0:100) were employed as the test liquids, thereby effects of the wettability on the liquid-gas interface formation process was able to be investigated as well. Consequently, the following four types of the interface behaviors were observed: (a) complete air entrapment with concave liquid-gas interfaces in the microstructures, (b) almost entire part of the microstructures are filled with air with convex liquid-gas interfaces, (c) whole wall is wetted, while a little portion of air is left in the microstructures (the air phase is surrounded by the liquid phase), and (d) the microstructures are completely filled with the liquid phase. Type (a) was achieved only when the advancing contact angle was larger than the angle of the final shape of the liquid-gas interfaces, whereas Type (b), Type (c), and Type (d) showed dependencies on both the geometry of the microstructures and the wettability. The results will qualitatively help a strategy for the fabrication of the microstructures to obtain more proper shape of the liquid-gas interface for maximizing the slip length and the resulting drag reduction effect in microchannels.
\end{abstract}

Key words : Liquid-gas interface, Laminar flow, Hydrophobicity, Drag reduction, Microstructures

\section{1. 緒言}

Lab-on-a-Chip や $\mu$ TAS と呼ばれるマイクロチップは，比界面積が大きいマイクロチャネルを用いることで様々 な物理化学的操作の効率を向上させることを目的として, 幅広い分野における応用が試みられている. しかし, 流体力学的観点からすると，比界面積の増加は壁面摩擦の増加による著しい圧力損失の増加を招く．この高い圧 力損失のために，マイクロスケールのポンプでは駆動に十分な圧力を生夕出すことができない場面も散見される ことから，マイクロチップにおける流体の駆動にはシリンジポンプなどを用いることが多い。また，ポンプの他 にも観察に用いる顕微鏡システムなどマイクロチップには多くの機器が接続されることから, マイクロチップは 携行使用が困難な”Chip in a lab”状態にあることも少なくない（Streets and Huang, 2013）。このような現状を打破す るためには，マイクロポンプの性能向上とともにマイクロチップの流体力学的な性能向上も必要となる.

マイクロチャネルの流体力学的な性能を向上させる手法の一つに，チャネル壁面に疎水性の微細構造を設け， 微細構造内にトラップした空気を見かけの壁面とすることによってスリップ流を発生させる手法が挙げられる.

\footnotetext{
No.16-00164 [DOI: 10.1299/transjsme.16-00164], J-STAGE Advance Publication date : 5 September, 2016

*1 正員, 東京理科大学 工学部（干125-8585 東京都葛飾区新宿 6-3-1）

*2 正員, 首都大学東京大学院 理工学研究科（干192-0397 東京都八王子市南大沢 1-1)

*3 首都大学東京大学院 理工学研究科

E-mail of corresponding author: yam@rs.tus.ac.jp
} 
チャネル内を流動する流体はチャネル壁面からの摩擦を受けるが，微細構造内の気相との界面においては摩擦抵 抗が無視できるほど小さいため, スリップ流の発生により流動抵抗の大幅な減少が可能であることが知られてい る (Rothstein, 2010, Lee et al., 2014, Vinogradova and Dubov, 2012).

Ou らはチャネル高さが 76-254 $\mu \mathrm{m}$ ，アスペクト比が 20 のプラスチック/ガラス製マイクロチャネルの壁面に直 径 $30 \mu \mathrm{m}$ の疎水性円柱を $30 \mu \mathrm{m}$ 間隔でアレイ状に配置した流路における圧力損失測定を行い，40\%を超える抵抗 低減率を得た（Ou et al., 2004）。また，この抵抗低減率から計算した滑り長さは約 $20 \mu \mathrm{m}$ であり，同じオーダーの 滑り長さは様々な疎水性微細構造を有寸る壁面においても計測されている (Choi and Kim, 2006, Srinivasan et al., 2013, Song et al., 2014).

微細構造による抵抗低減のメカニズムは気液界面におけるスリップ流によって説明されるため，抵抗低減率の 更なる向上のためには，トラップされた気泡の形状や微細構造自身の形状が流動に及ぼす影響を明らかにし，微 細構造を最適化する必要がある（Rothstein, 2010, Butt et al., 2013, Lee et al., 2014). Byun らは微細構造を有する PDMS 製マイクロチャネル内におけるPIVによる滑り長さの計測および微細構造内気液界面近傍の流動構造の可 視化を行った（Byun et al., 2008）。この実験により, 微細構造内に気泡がトラップされ, その気液界面形状は微細 構造側に凸であることや，曲率を持つ気液界面形状の影響により流路断面方向にも速度を持つことが明らかにさ れた。 さらに，微細構造の幅が広がるにつれて液相が微細構造内に侵入していく様子も観察された. 微細構造側 に凸形状となる気液界面は Tsai らの可視化実験においても観察されている（Tsai et al., 2009）一方で, 抵抗低減率 は気液界面形状に依存することが知られており，抵抗低減率が最大となる気液界面形状は，Byun らや Tsai らが 明らかにした界面形状に反して流路側にわずかに凸の場合である（Hyväluoma and Harting, 2008, Hyväluoma et al., 2011, Karatay et al., 2013).

上述のように，微細構造内における気液界面形状が制御可能となれば抵抗低減効果が向上寸ることが予想され る. そこで, 本研究では界面形成メカニズムの解明を目的とし, 疎水性微細構造を有するマイクロチャネルにお ける気液界面の可視化実験を行うことにより微細構造の形状および濡孔性が微細構造内における気液界面の形成 に与える影響について定性的に明らかにする. 実験には微細構造の異なる 4 つのマイクロチャネルを使用し, エ タノール含有率を変化させた純水一エタノール混合液を使用することで濡れ性を変化させる.

\section{2. 実験装置および方法}

本研究では, 図 1 に示寸ように中央部に矩形のスリットを有する厚さ $100 \mu \mathrm{m}$ の Test spacer（SUS304 製）の上 下面をそれぞれアクリル板と Top cover（SUS304 製）および Under cover（SUS304 製）で挟み込み一定トルクで ボルト締めすることで幅 $1 \mathrm{~mm}$, 深さ $100 \mu \mathrm{m}$ ，長さ $50 \mathrm{~mm}$ のマイクロチャネル (等価水力直径 : $182 \mu \mathrm{m}$ ) を作製 した．さらに，Test spacerのマイクロチャネル側壁となる部分には図 2 に示すようにワイヤー放電加工により規 則的な矩形微細構造を作製後，トリアジンチオールのコーティング（被膜厚さ：50-100 nm 程度）による撥水加 工を施した. 本研究では図 3 に定義する微細構造形状の異なる 4 種類のマイクロチャネルを使用した. 各チャネ ルの微細構造形状は表 1 に示寸通りである. また, チャネルの上下壁面となるアクリル板および Under cover には コーティングを施していない. このため, 本研究では可視化を行う平面を流路深さ方向における中央 $(z=50 \mu \mathrm{m})$ とし，流動は二次元流動として扱う.

可視化を行うために Top cover 中央部には開口部を設けてあり, 流路上面からアクリル板越しに流動を観察する ことが可能になっている。本研究では流路入口から約 $5 \mathrm{~mm}$ 下流にズームレンズを装着した高速度カメラ

（VW-9000, KEYENCE）を設置し，空気で満たされたマイクロチャネル内において気液界面の挙動の可視化を行 った（図 4). 実験では, 供試流体と空気により形成される気液界面の前進および微細構造近傍における気液界面 の挙動の可視化を行い, 前者の場合には長距離ズームレンズ (VH-Z35, KEYENCE) の倍率 200 倍, フレームレ ート $1000 \mathrm{fps}$ で撮影を行い，後者の場合には高倍率ズームレンズ（VH-Z450, KEYENCE）の倍率 450 倍，フレー ムレート $4000 \mathrm{fps}$ で撮影を行った.

供試流体には純水とエタノールの混合液を用い, エタノール含有率（質量分率）を0\%から 100\%まで変化させ た供試流体を使用した。供試流体はシリンジポンプ（Nexus 6000，Chemyx Inc）によりチャネル下部から一定流 量で流路部へと導入した. レイノルズ数は $R e=1$ とし，この際の助走区間は $10 \mu \mathrm{m}$ 程度となることから, 可視化 


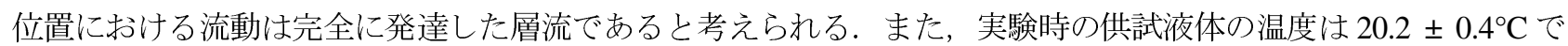
あった. なお, 便宜上これらの供試流体は以下においては「エタノール 50\%」のようにエタノール含有率で示す。

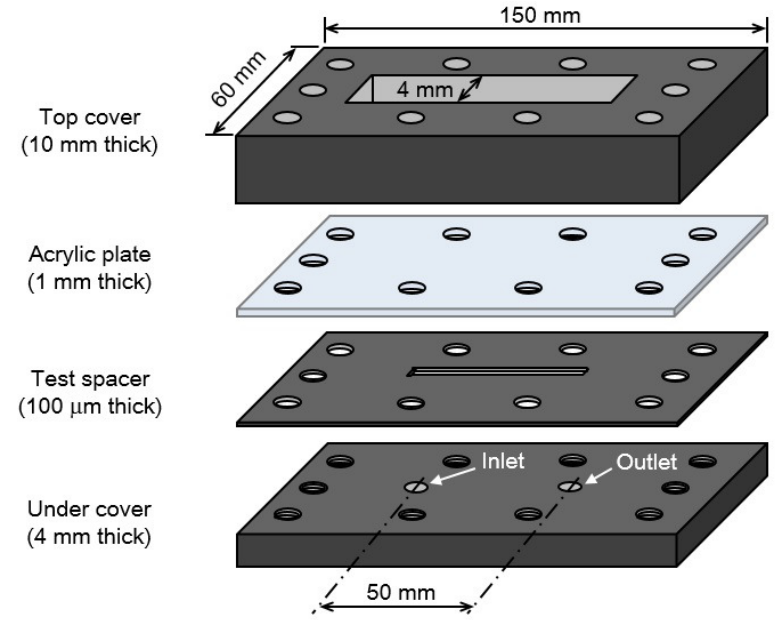

Fig. 1 Components of the microchannel. Top cover, Test spacer, and Under cover are made of SUS304. All components are bolted with a constant torque.

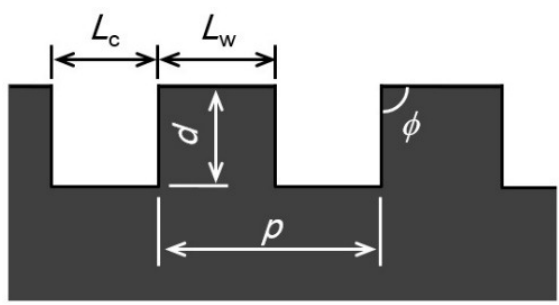

Fig. 3 Definition of the dimensions of the microstructures on the side wall.

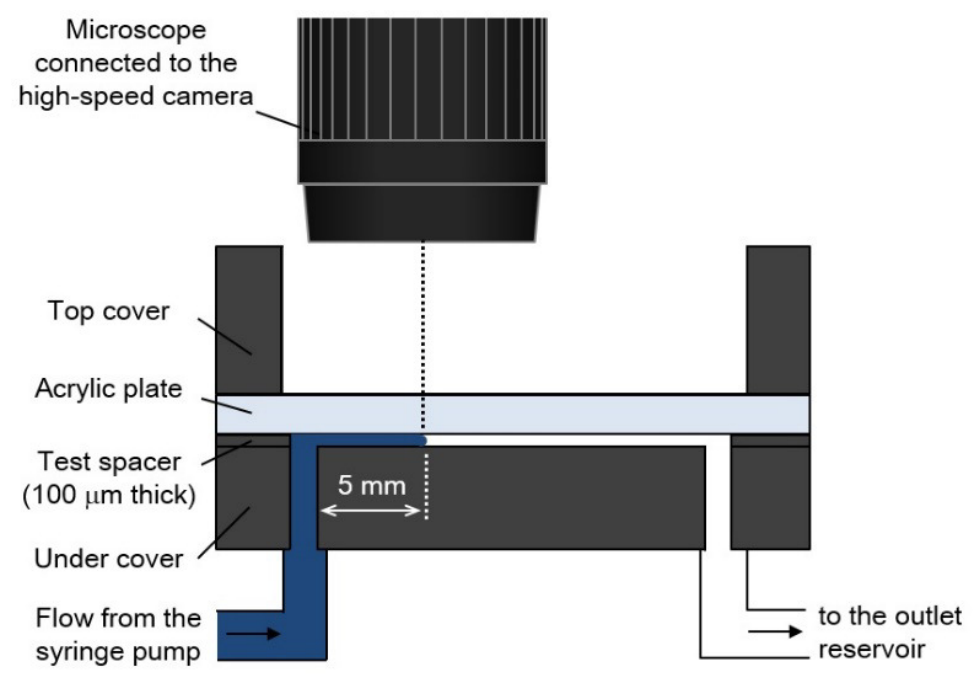

Fig. 4 Schematic of the experimental setup for the visualization. An advancing liquid-gas interface and the air entrapment in the microstructures were captured through the acrylic plate by a combination of a high-speed camera and a zoom lens (1000 fps and 200x for the advancing interface and $4000 \mathrm{fps}$ and 450x for the air entrapment.) The high-speed imaging was carried out at $5 \mathrm{~mm}$ downstream of the channel inlet. The flow rate was controlled by a syringe pump and the Reynolds number were set to $R e=1$. 


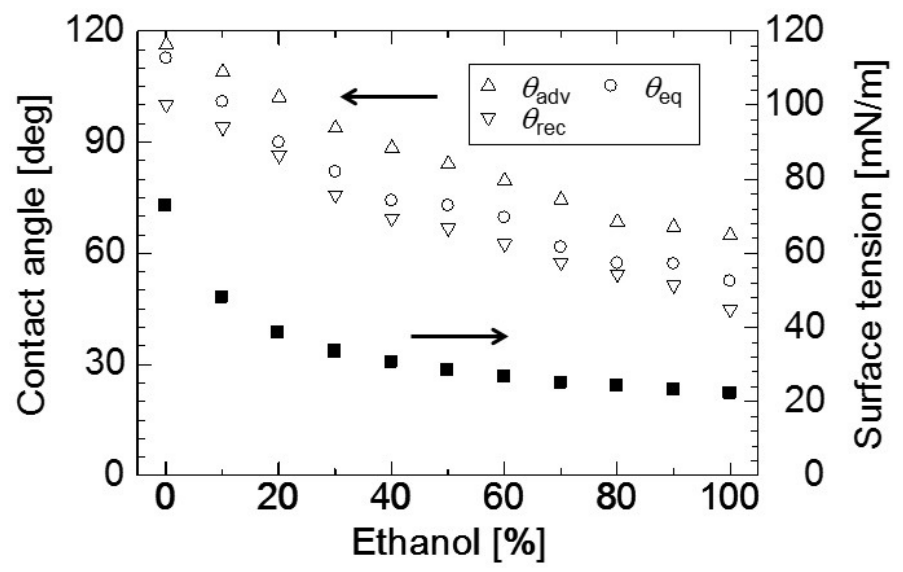

Fig. 5 Measured contact angles (the advancing contact angle $\theta_{\mathrm{adv}}$, the receding contact angle $\theta_{\mathrm{rec}}$, and the equilibrium contact angle $\theta_{\mathrm{eq}}$ ) and the surface tension (Vázquez et al., 1995) of the ethanol-water mixture.

\section{3. 実験結果及び考察}

\section{$3 \cdot 1$ 接触角の計測}

可視化実験に先立ち，マイクロチャネルの濡れ性を評価するため，トリアジンチオールをコーティングした SUS304 平板に供試流体を滴下し, 液滴の静的および動的接触角を計測した. 液滴はシリコンチューブを介して シリンジポンプに接続した先端が平坦な針（34G，リアクトシステム）からの自由落下により生成した。シリン ジポンプによる送液流量を $0.01 \mathrm{~mL} / \mathrm{min}$ に設定することで安定的に直径 $1.97 \pm 0.04 \mathrm{~mm}($ 約 $4 \mu \mathrm{L})$ の液滴の生成を 実現した。平衡 (静的) 接触角は，壁面上の液滴を側方から撮像した画像から $\theta / 2$ 法により計測した。また，前 進および後退接触角は，壁面上の液滴に針を挿入し，それぞれシリンジポンプにより $0.01 \mathrm{~mL} / \mathrm{min}$ および 0.05 $\mathrm{mL} / \mathrm{min}$ で送液または吸引した際に三重線が移動する直前の角度とした. 図 5 に計測した平衡接触角 $\theta_{\mathrm{eq}}$, 前進接 触角 $\theta_{\mathrm{adv}}$, 後退接触角 $\theta_{\mathrm{rec}}$, および表面張力（Vázquez et al., 1995）を示す。図より, エタノ一ル含有率の増加とと もに接触角は線形に減少寸ることがわかる.

\section{$3 \cdot 2$ 気液界面と三重線の移動}

マイクロチャネル側壁に設けた微細構造内へ気泡をトラップする過程を明らかにするため, Channel C（微細構 造間隔 $L_{\mathrm{w}}=100 \mu \mathrm{m}$, 微細構造幅 $L_{\mathrm{c}}=100 \mu \mathrm{m}$, 微細構造深さ $\left.d=100 \mu \mathrm{m}\right)$ において流路内を移動する気液界面お よび三重線（気体・液体・固体の各相が接する線）の可視化を行った. 図 $6 \mathrm{a}$ はエタノール $0 \%($ 純水）を $R e=1$ で流動させた際の気液界面の移動の連続画像である（倍率 200 倍, 撮影速度 $1000 \mathrm{fps}$ ）。供試流体の流動方向は図 中左から右であり，気液界面は深さ方向への湾曲の影響により黒く映っている（図中上側の側壁付近の気液界面 は視認性向上のために破線によるガイドを追加している). 図より, 流路中央部（以下, 主流と呼ぶ）の気液界面 は下流側に凸形状であり，流路壁面では微細構造内部に気泡がトラップされていることが分かる．この際の主流 の気液界面および流路側壁上を移動する三重線の各時刻における流路軸方向の位置を図 7 に示す. 図より，主流 の気液界面は常に三重線に先行してほぼ一定の速度で移動しており，反対に三重線は微細構造の上流側エッジ部 においてピン止めされるために断続的に移動していることがわかる.また，三重線がピン止めされている微細構 造上流側のエッジから微細構造下流側のエッジへと移動する直前において主流の気液界面と三重線の距離が最大 となり, 界面の曲率も最大となる (図 $6 \mathrm{a}, 200 \mathrm{~ms}$ ). そして, 微細構造下流側のエッジに接した三重線は非常に 短時閒の間に壁面上を移動し，下流側に位置する微細構造の上流側エッジにおいて再びピン止めされることが明 らかになった.一方，エタノール 100\%の場合 (図 6b) ではエタノール $0 \%$ の場合と比較して濡れが拡がりやすく， Channel C 内で形成される気液界面の形状も下流側にわずかに形状となった。 このため, 図 8 に示すように各時 刻において主流の気液界面は流路側壁上を移動する三重線よりも流路軸方向位置が上流側となった。 なお，エ夕 ノール 100\%の場合には三重線が微細構造内へと侵入していったため気泡のトラップは起こらず，また三重線の ピン止めも観察されなかった. 
(a) Ethanol $0 \%$

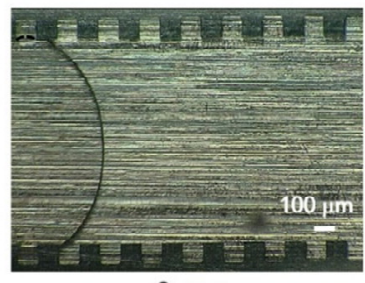

$0 \mathrm{~ms}$

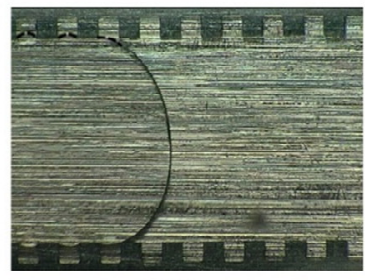

$100 \mathrm{~ms}$

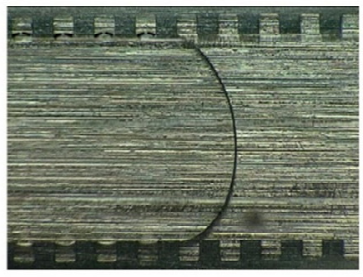

$200 \mathrm{~ms}$

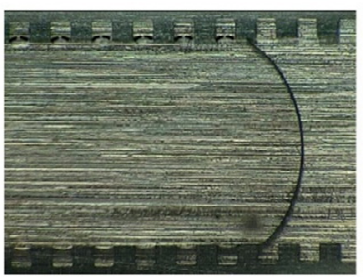

$300 \mathrm{~ms}$ (b) Ethanol $100 \%$

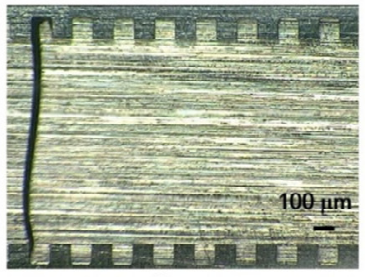

$0 \mathrm{~ms}$

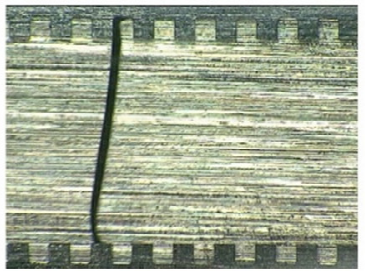

$30 \mathrm{~ms}$

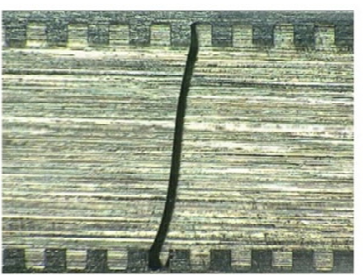

$60 \mathrm{~ms}$

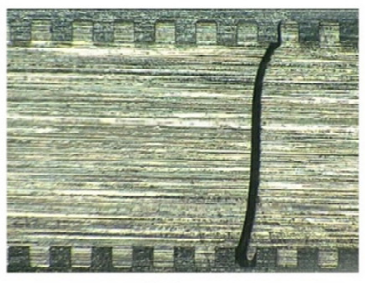

$90 \mathrm{~ms}$

Fig. 6 Successive images of advancing liquid-air interfaces in (a) pure water (Ethanol 0\%) and (b) pure ethanol (Ethanol $100 \%$ ) flows in Channel C (channel width: $1 \mathrm{~mm}$, channel depth: $100 \mu \mathrm{m})$ recorded at $1000 \mathrm{fps}$ with a magnification of $200 \times$. Flow direction is from left to right.

\section{3 - 3 微細構造における気液界面の形成}

上述のように，主流の気液界面はほぼ一定の速度で移動しているのに対して三重線には特徵的な挙動が観察さ れたため, 微細構造近傍における三重線および気液界面のより詳細な観察を行った. エタノール $0 \%, 50 \%, 70 \%$, 100\%の場合の界面および三重線の移動を図 9 に示寸. 微細構造近傍における三重線および気液界面の挙動はエ夕 ノール含有率により大きく異なり，(a) 三重線がピン止めされ，気液界面が微細構造に侵入せず空気をトラップ する場合，（b）ピン止めされた三重線が主流の気液界面の進行に伴い微細構造に侵入するが空気をトラップする 場合，(c) 三重線がほとんどピン止めされずに微細構造に侵入し，全ての壁面が濡れるがキャビティ内に気泡も 存在する場合, および (d) 三重線が微細構造に侵入し, 微細構造内を液相で完全に満たす場合, の 4 つに大別す ることができる．このうち，特に（a）や（b）が発生する条件を明らかにすることは，気泡トラップによる流動 の抵抗低減効果を得るために重要となるため, 以下においてそれぞれの場合の詳細なメカニズムについて述べる. 
(a) Ethanol $0 \%$

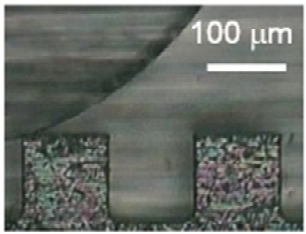

$0 \mathrm{~ms}$

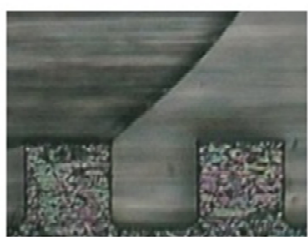

$11.5 \mathrm{~ms}$

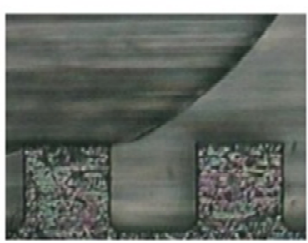

$12.8 \mathrm{~ms}$

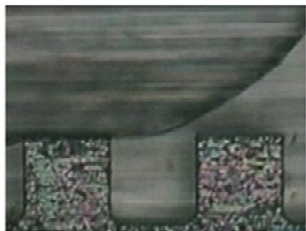

$27.3 \mathrm{~ms}$

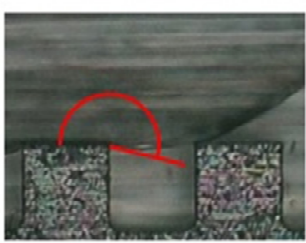

$43.5 \mathrm{~ms}$

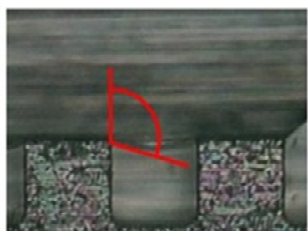

$62.3 \mathrm{~ms}$ (b) Ethanol $50 \%$

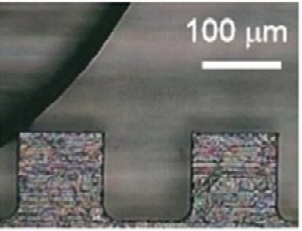

$0 \mathrm{~ms}$

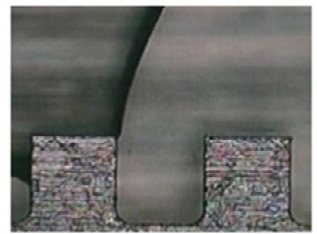

$2.0 \mathrm{~ms}$

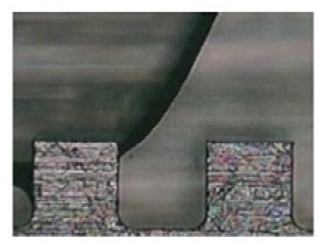

$5.8 \mathrm{~ms}$

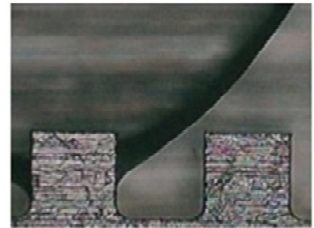

$14.5 \mathrm{~ms}$

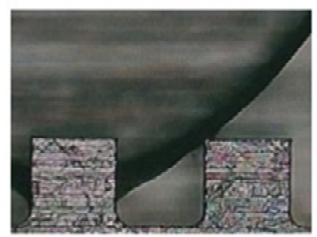

$18.3 \mathrm{~ms}$

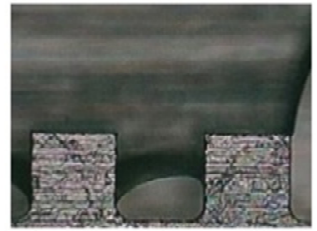

$21.3 \mathrm{~ms}$ (c) Ethanol $70 \%$

(d) Ethanol $100 \%$

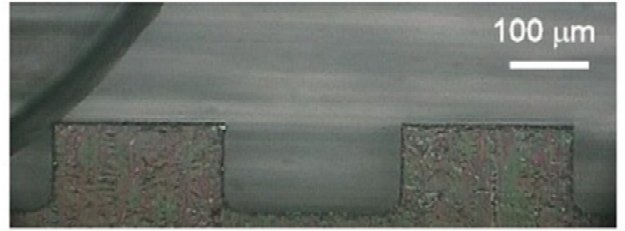

$0 \mathrm{~ms}$

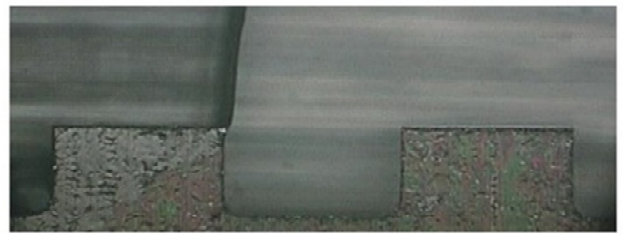

$6.5 \mathrm{~ms}$

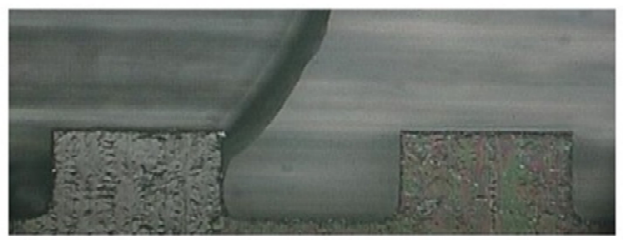

$11.0 \mathrm{~ms}$

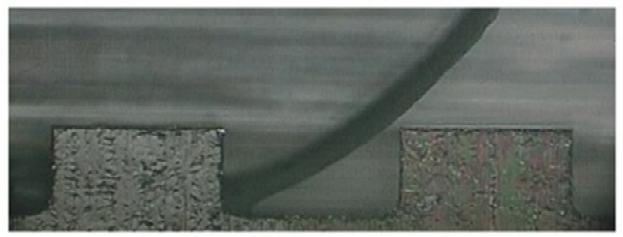

$25.5 \mathrm{~ms}$

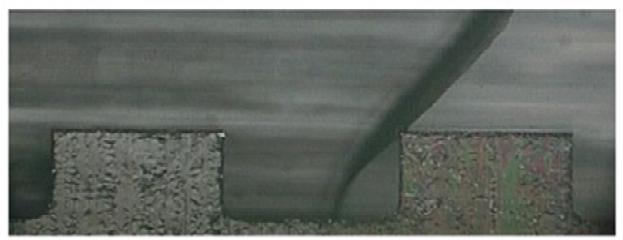

$27.8 \mathrm{~ms}$

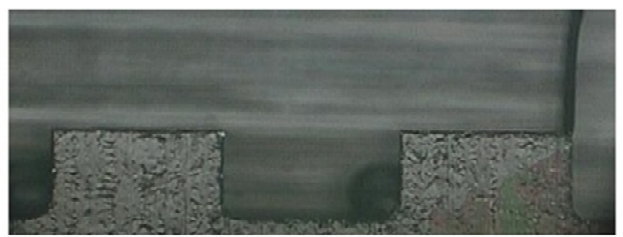

$32.5 \mathrm{~ms}$

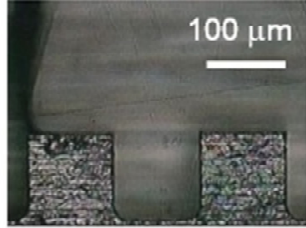

$0 \mathrm{~ms}$

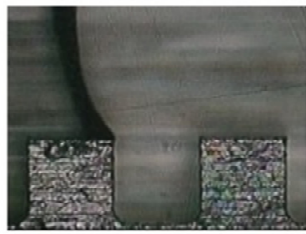

$1.0 \mathrm{~ms}$

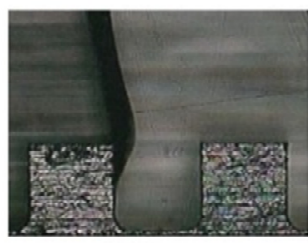

$2.2 \mathrm{~ms}$

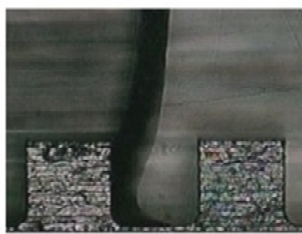

$7.5 \mathrm{~ms}$

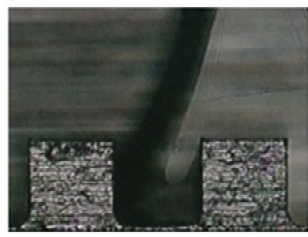

$10.8 \mathrm{~ms}$

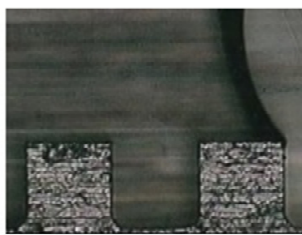

$15.7 \mathrm{~ms}$

Fig. 9 Selected sequences of advancing liquid-gas interfaces and triple lines $(R e=1)$ in Channel C (Ethanol 0\%, 50\%, and 100\%) or Channel D (Ethanol 70\%) recorded at 4000 fps with a magnification of 450x. The liquid phases are (a) pure water (Ethanol 0\%), (b) water-ethanol mixture (Ethanol 50\%), (c) water-ethanol mixture (Ethanol 70\%), and (d) pure ethanol (Ethanol 100\%), respectively. The gas phase is air. Flow directions are from left to right.

図 7 においても見られたように，エタノール 0\%の場合には二つの微細構造間の壁面上の下流側エッジにおい てピン止めが起こり，比較的長い時間三重線が移動せず，気液界面の曲率が増大していく（図 9a). 微細構造近 傍の気液界面は, 主流の気液界面の移動に伴い微細構造の下流側のエッジと, 図の水平方向を基淮として $180^{\circ} に$ 近い角度で接触するが，この角度は供試流体と壁面との前進接触角よりも大きいため（図 5), 三重線は接触角を 
減少させる方向へと短時間のうちに移動し，再び下流側の微細構造のエッジにおいてピン止めされることが明ら かになった.この三重線の挙動により供試流体は微細構造内には侵入せず，微細構造内にトラップされた空気と 微細構造方向に凸形状の気液界面を形成した。 また，気液界面が微細構造の下流側エッジと接触する直前では， 三重線の位置における気液界面と壁面が形成する角度は $180^{\circ}$ 超えており（図 $9 \mathrm{a}, t=43.5 \mathrm{~ms}$ ), 微細構造側面を 基準として計測した接触角は約 $100^{\circ}$ とった（図 $9 \mathrm{a}, t=62.3 \mathrm{~ms}$ ). このような三重線の挙動はエタノール $0 \%$, 10\%，20\%の場合に確認されており，それぞれの供試流体の前進接触角は $100^{\circ}$ 上回っていることから（挙動の 変化が見られたエタノール 30\%の前進接触角は $93.8^{\circ}$ ), (a) が発生する条件は前進接触角によって決定されると 考えられる. 同様の結果は, Byun らの実験 $\left(0.3<d / L_{\mathrm{c}}<1.5\right)$ やTsai らの実験 $\left(0.6<d / L_{\mathrm{c}} \leq 2.5\right)$ においても得ら れている (Byun et al., 2008, Tsai et al., 2009). なお, Byun らは， $L_{\mathrm{c}}$ が大きい場合（ $d=30 \mu \mathrm{m} ）$ (a) の界面形成 から数秒後に液相が微細構造内に侵入していくことを報告しているが，これは流動に伴い液相内の圧力が増加し ていくことが原因であると考えられる（Rothstein, 2010, Sbragaglia and Prosperetti, 2007）.

図 10 に三重線の挙動のエタノール濃度と微細構造アスペクト比の関係を示す。上述の通り，(a) が観察された 条件はエタノール含有率が 20\%以下の場合であり微細構造形状には依存しないが，一方で（b）の場合には主流 の気液界面の進行と共に微細構造のエッジにおける接触角が増加し, 最終的に接触角が前進接触角を上回ること によりデピニングが起こり三重線が微細構造内に侵入する。しかし，三重線が微細構造底部に到達する以前に主 流の気液界面が微細構造の下流側のエッジに到達するため, 微細構造内に空気がトラップされる。このような挙 動が観察された場合の平衡接触角は 90以下であり, 微細構造内に形成される気液界面は微細構造方向に凹形状 であった。（b）の場合においてトラップされる気泡の量は，デピニングが起こり三重線が微細構造内に侵入する ため, 供試液体の濡れ性が高くなるにつれて減少する. そして, 濡れ性の増加, または微細構造のアスペクト比 $d / L_{\mathrm{c}}$ の減少に伴って三重線の挙動は（c）へと移行し，さらに濡れ性が増加すると（d）へ移行する．なお，(c) においては, 図 11 に例示するようにアスペクト比が高いチャネルのほうが微細構造内に残存する気泡量が多くな ることが明らかになった。

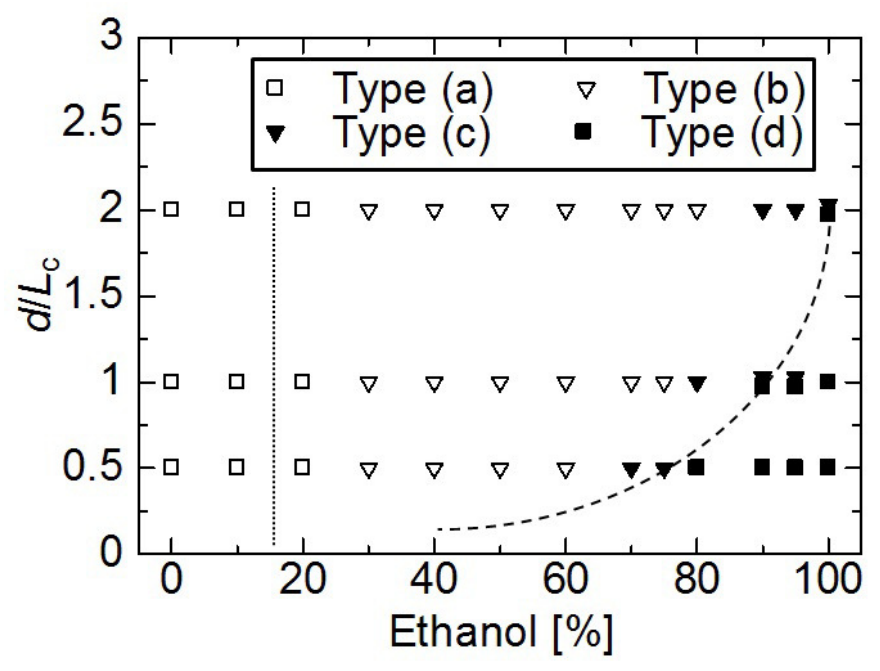

Fig. 10 A pattern map for four different triple line behaviors: (a) the air entrapment occurs as pinned triple lines form concave liquidair interfaces between the top edges of the microstructures, (b) the air entrapment occurs but the liquid-air interfaces are not at the edges of the microstructure but in the structures due to the depinning, (c) liquid wets all walls inside the microstructures and only a part of air remains in the microstructures due to the incursion of the liquid phase, and (d) complete incursion of the liquid phase in the microstructures. Dotted and dashed lines are eye guides for the boundary between Type (a) and Type (b) and the boundary between Type (c) and Type (d), respectively. 


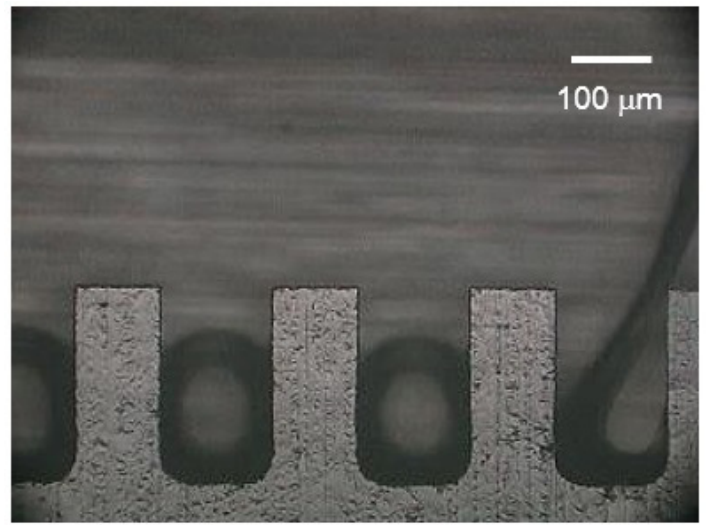

Fig. 11 Type (c) air entrapment in Channel $\mathrm{A}\left(L_{\mathrm{c}}=L_{\mathrm{w}}=100 \mu \mathrm{m}, d=200 \mu \mathrm{m}\right)$. The liquid phase is Ethanol 100\%. The air phase is surrounded by the liquid phase (entire channel wall is wetted).

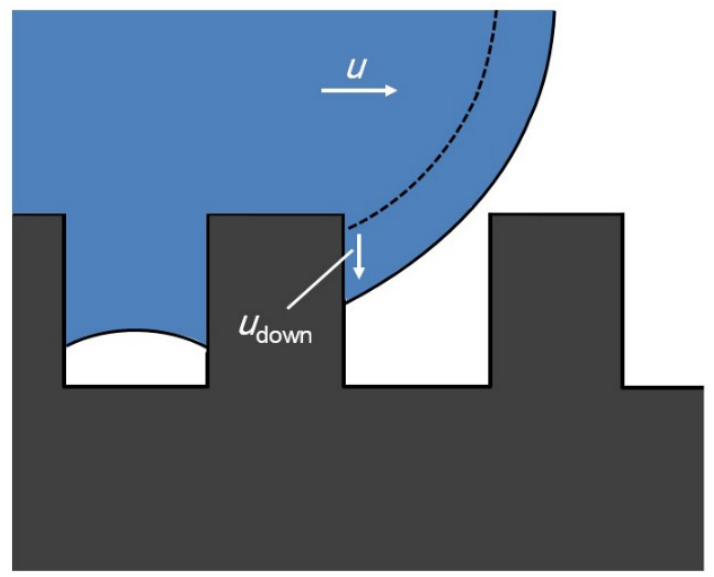

Fig. 12 Definitions of $u$ and $u_{\text {down }}$. Velocity of the three-phase contact line was measured and a velocity component, which is orthogonal to the main flow direction and away from the main channel, was extracted and defined as $u_{\text {down }}$.

\section{3-4 三重線および気液界面の挙動の予測}

前節の結果より，任意の微細構造において，微細構造の角度 $\phi$ （図 3）と前進接触角により（a）の挙動を，主 流流速に対する三重線の相対的な速度と微細構造の形状により（b）〜（d）のうちのどの挙動を示すのかを予測 することが可能であると考えられる。一般に, 界面の形状が歪んでいる場合には表面張力により三重線は歪みを 解消寸る万向に大きな速度を持つ. 図 12 に示すように, 微細構造内に侵入する三重線は侵入の前後で移動方向を 90変更することから，流動方向へ移動を続ける（バルクの）界面に対して三重線が進行方向を $90^{\circ}$ 変更すること により生じる壁面近傍の界面の歪夕は微細構造到達直後に最大となり, 微細構造側壁において三重線の速度も増 加することが予想される. 従って, この壁面上を移動する三重線の平均移動速度 $u_{\text {down }}$ と微細構造の形状の関係か ら気液界面の挙動が予測可能になると考えられる．図 13 に，主流流速 $u$ により無次元化した $u_{\mathrm{down}}$ を示す．計測 の結果， $u_{\mathrm{down}}$ はエタノール含有率の増加と共に増加していき，エタノール $100 \%$ の場合には主流流速の約 6 倍と なることが明らかになった。 ここで, 主流の気液界面が微細構造の通過に要する時間は $L_{\mathrm{c}} / u$, 三重線が微細構造 の上端から下端へ移動するのに要する時間は $d / u_{\mathrm{down}}$ と概算することができるので, $L_{\mathrm{c}} / u=d / u_{\mathrm{down}}$ を満たす時に三 重線の挙動は (b) から (c) へと変化すると考えられる. 図 14 にアスペクト比 $d / L_{\mathrm{c}}$ と三重線の無次元化速度 $u_{\mathrm{down}} / u$ の関係を示す. 図において, 点線で示す（b）と（c）の境界線の傾きは $d / L_{\mathrm{c}} \approx 2 / 3 \times u_{\mathrm{down}} / u$ となった. 上述の関係 を基にした予測 $\left(d / L_{\mathrm{c}}=u_{\mathrm{down}} / u\right)$ と比較すると, 本研究では $u_{\mathrm{down}}$ を約 1.5 倍大きく計測している可能性があるが, これは実際の流路においてはエッジ部におけるピン止めおよび主流の気液界面形状の影響を考慮する必要があり， さらに三重線の速度は一定であるとは限らないことが影響していると考えられる．また，(c) から（d）へと変化 する場合には三重線が微細構造内を移動する時間は $\left(d+L_{\mathrm{c}}\right) / u_{\mathrm{down}}$ と概算できるので, $(\mathrm{c})$ と（d）の境界線も図中 の破線のように直線で表現することが可能である。 


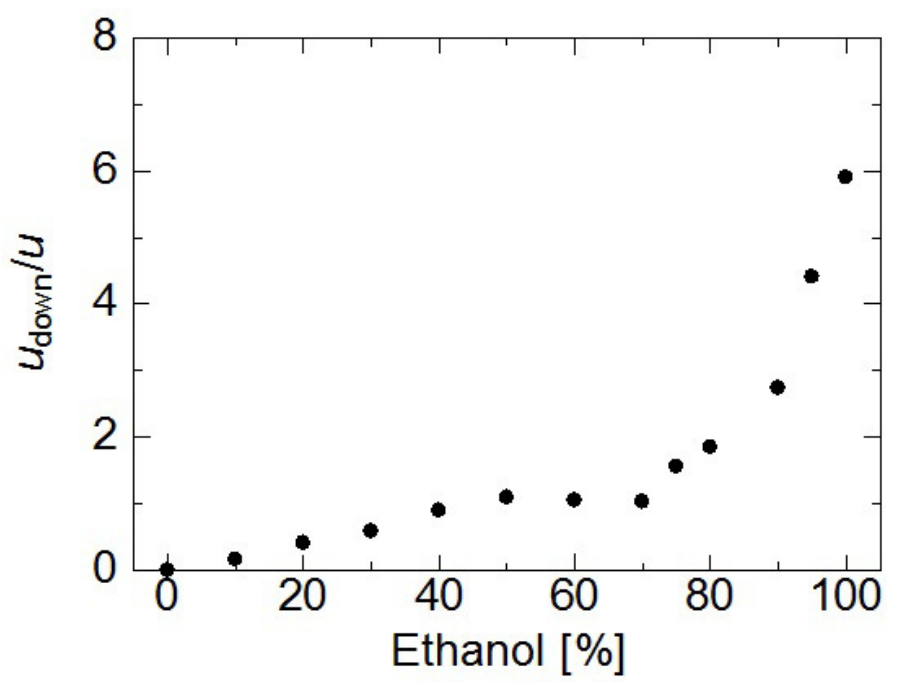

Fig. 13 Dependency of the normalized velocity of the triple line entering the microstructure $u_{\mathrm{down}} / u$ on the ethanol concentration.

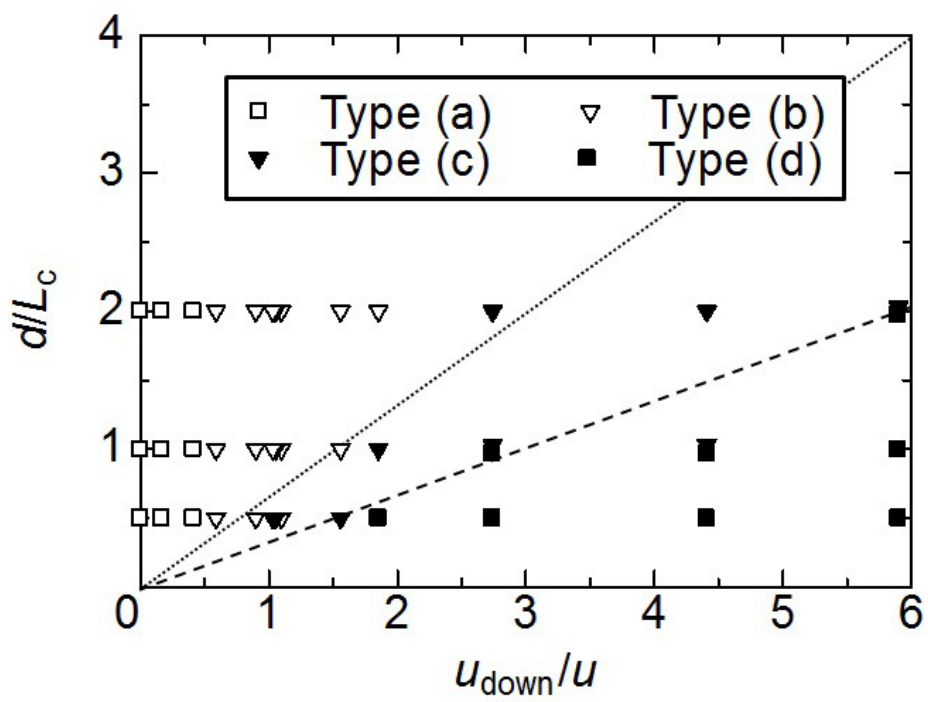

Fig. 14 A relationship between $d / L_{\mathrm{c}}$ and $u_{\mathrm{down}} / u$. Dotted and dashed lines are eye guides for the boundary between Type (b) and Type (c) and the boundary between Type (c) and Type (d), respectively.

\section{4. 結 言}

本研究では, 微細構造を有するマイクロチャネルにおいて空気が満たされた状態から供試液体をチャネル内に 流入させ，微細構造内に気液界面が形成される過程の可視化を行った。供試流体にはエタノール含有率を $0 \%$ か ら 100\%まで変化させた水一エタノール混合液を使用し, 壁面の濡れ性を変化させた. 微細構造形状の異なる 4 種類のチャネルを用いて $R e=1$ の条件において可視化実験を行った結果, 微細構造の形状および濡れ性の変化に より三重線および気液界面の挙動が大きく変化することが定性的に明らかになった．これらの挙動は以下の 4 パ ターンに大別することができる. (a) 三重線が微細構造内に侵入せず，微細構造内に空気がトラップされる（気 液界面形状は微細構造方向に凸), (b) 三重線は微細構造内に侵入するが, 微細構造内に空気がトラップされる (気 液界面形状は微細構造方向に凹), (c) 微細構造の壁面は完全に濡れるが, 一部の空気は微細構造内に残留する (空 気と壁面との間には液相が存在する)，(d) 微細構造の壁面が完全に濡れ，空気のトラップも起こらない．以上の 4 パターンのうち，（a）は前進接触角が閾值よりも大きい場合（本実験では約 100）に発生し，（b）～（d）は主 流流速と三重線の速度, および微細構造の形状の関係によりどのパターンが出現するかが決定される. 以上の結 
果は, マイクロチャネルにおいて空気のトラップによる抵抗低減効果を得る目的で設けられる微細構造形状の最 適化に有用であると考えられる。

\author{
謝辞 \\ 本研究の一部は（独）日本学術振興会科学研究費補助金・基盤研究(C)（No. 15K05801）の助成を受けた.ここ \\ に感謝の意を表する.
}

\title{
References
}

Butt, H.-J., Semprebon, C., Papadopoulos, P., Vollmer, D., Brinkmann, M. and Ciccotti, M., Design principles for superamphiphobic surfaces, Soft Matter, Vol. 9 (2013), pp. 418-428.

Byun, D., Kim, J., Ko, H. S. and Park, H. C., Direct measurement of slip flows in superhydrophobic microchannels with transverse grooves, Physics of Fluids, Vol. 20 (2008), 113601.

Choi, C.-H. and Kim, C.-J., Large slip of aqueous liquid flow over a nanoengineered superhydrophobic surface, Physical Review Letters, Vol. 96 (2006), 066001.

Hyväluoma, J. and Harting, J., Slip flow over structured surfaces with entrapped microbubbles, Physical Review Letters, Vol. 100 (2008), 246001.

Hyväluoma, J., Kunert, C. and Harting, J., Simulations of slip flow on nanobubble-laden surfaces, Journal of Physics Condensed Matter, Vol. 23 (2011), 184106.

Karatay, E., Haase, A. S., Visser, C. W., Sun, C., Lohse, D., Tsai, P. A. and Lammertink, R. G. H., Control of slippage with tunable bubble mattresses, Proceedings of National Academy of Sciences, Vol. 110, No. 21 (2013), pp. 8422-8426.

Lee, T., Charrault, E. and Neto, C., Interfacial slip on rough, patterned and soft surfaces: A review of experiments and simulations, Advances in Colloid and Interface Science, Vol. 210 (2014), pp. 21-38.

$\mathrm{Ou}$, J., Perot, B. and Rothstein, J. P., Laminar drag reduction in microchannels using ultrahydrophobic surfaces, Physics of Fluids, Vol. 16, No. 12 (2004), pp. 4635-4643.

Rothstein, J. P., Slip on superhydrophobic surfaces, Annual Review of Fluid Mechanics, Vol. 42 (2010), pp. 89-109.

Sbragaglia, M. and Prosperetti, A., A note on the effective slip properties for microchannel flows with ultrahydrophobic surfaces, Physics of Fluids, Vol. 19 (2007), 043603.

Song, D., Daniello, R. J. and Rothstein, J. P., Drag reduction using superhydrophobic sanded Teflon surfaces, Experiments in Fluids, Vol. 55 (2014), 1783.

Srinivasan, S., Choi, W., Park, K.-C., Chhatre, S. S., Cohen, R. E. and McKinley, G. H., Drag reduction for viscous laminar flow on spray-coated non-wetting surfaces, Soft Matter, Vol. 9 (2013), pp. 5691-5702.

Streets, A. M. and Huang, Y., Chip in a lab: Microfluidics for next generation life science research, Biomicrofluidics, Vol. 7 (2013), 011302.

Tsai, P., Peters, A. M., Pirat, C., Wessling, M., Lammertink, R. G. H. and Lohse, D., Quantifying effective slip length over micropatterned hydrophobic surfaces, Physics of Fluids, Vol. 21 (2009), 112002.

Vázquez, G., Alvarez, E. and Navaza, M., Surface tension of alcohol + water from 20 to $50^{\circ} \mathrm{C}$, Journal of Chemical and Engineering Data, Vol. 40 (1995), pp. 611-614.

Vinogradova, O. I. and Dubov, A. L., Superhydrophobic textures for microfluidics, Mendeleev Communications, Vol. 22 (2012), pp. 229-236. 